\title{
THE EFFECT OF TILLAGE SYSTEM AND HERBICIDE APPLICATION ON WEED INFESTATION OF CROPS OF WINTER SPELT WHEAT (Triticum aestivum ssp. spelta L.) CULTIVARS
}

\author{
Sylwia Andruszczak, Piotr Kraska, Ewa Kwiecińska-Poppe, Edward Pałys \\ Department of Agricultural Ecology, University of Life Sciences in Lublin \\ Akademicka 13, 20 - 950 Lublin, Poland \\ e-mail: sylwia.andruszczak@up.lublin.pl
}

Received: 12.12 .2012

\begin{abstract}
Based on a 3-year field experiment conducted on medium heavy mixed rendzina soil, the present study evaluated the effect of chemical plant protection on the species composition, number and air-dry weight of weeds infesting crops of winter spelt wheat cultivars ('Frankenkorn', 'Badengold', 'Schwabenspeltz', and 'Oberkulmer Rotkorn') sown under ploughing and ploughless tillage systems. Ploughing tillage involved skimming done after harvest of the previous crop and pre-sowing ploughing, while in the ploughless tillage system ploughing was replaced with cultivating. Chemical weed control included the application of the herbicides Mustang 306 SE and Attribut 70 WG. Plots where the herbicides were not used were the control treatment.

On average, from 21 to 30 weed species colonised the winter spelt wheat crops compared. Galium aparine and Apera spica-venti occurred in greatest numbers and their percentage in the total number of weeds was estimated at 26-35\% and $17-25 \%$, respectively. The cultivar 'Frankenkorn' was the least weed-infested. Both the number of weeds in the crop of this cultivar and their above-ground dry weight were lower compared to the other cultivars. The use of reduced tillage significantly increased the air-dry weight of weeds compared to ploughing tillage. Nevertheless, it should be indicated under ploughless tillage conditions the application of chemical crop protection reduced weed biomass by $59 \%$ compared to the control treatments without crop protection.
\end{abstract}

Key words: Triticum aestivum ssp. spelta, reduced tillage, weeds, chemical control

\section{INTRODUCTION}

Due to high costs of conventional tillage, in recent years no-ploughing techniques have been gaining increasing importance. Most frequently, they involve shallower ploughing or the complete elimination of the plough and replacing it with other implements [1]. The results of many studies show that reduced tillage, apart from changes in the basic physical, chemical and biological properties of soil, can also cause changes in weed infestation of the crop [2, 3, 4]. Different tillage methods create different plant growth and development conditions, leading not only to quantitative changes in weed communities, but also to qualitative ones. It is advisable to investigate the nature of these changes not only for cognitive reasons, but also for practical and economic reasons, since information on the relationships of particular weed species or communities with specific tillage systems can be of key importance in constructing weed management programmes $[5,6,7]$.

The existing research in this area is not entirely unambiguous. In assessing weed infestation of winter wheat and winter triticale, Ma fe $\mathrm{cka}$ et al. [8] showed a higher number and weight of weeds in ploughed plots compared ploughless tillage. At the same time, the elimination of ploughing slightly increased the species richness of weed communities accompanying winter cereals. In turn, W e be r and Hryń c z u k [9] as well as $\mathrm{K} \mathrm{r}$ a s k a [10] indicate higher weed infestation of fields under no-ploughing conditions. What is more, reduced tillage combined with monoculture cropping can result in a change from weed communities with a relatively high number of taxa to very simplified communities consisting of only several dominant species $[4,7]$. According to Trzcińska-Tacik [11], the harmfulness of weed communities with low biodiversity and a quantitative prevalence of one or several weed species is often greater than that of a community consisting of a large number of taxa that occur in small numbers. 
Many authors are of opinion that the effects of different tillage systems in the development of a crop community largely depend on agronomic factors, in particular crop rotation and herbicide protection $[2,5$, $7,12]$. The choice of cultivated species and cultivars in terms of their weed-competitive ability is also of major importance $[13,14,15,16,17]$. It is therefore advisable to make an evaluation of spelt cultivars grown in Poland with a view to assessing this trait.

The aim of the present study was to determine the effect of ploughing and ploughless tillage on weed infestation of crops of selected winter spelt wheat cultivars under the conditions of application of chemical plant protection.

\section{MATERIALS AND METHODS}

A field study was carried out in the period 2009-2011 at the Bezek Experimental Farm located near the city of Chelm. The experiment was established on medium heavy mixed rendzina soil derived from chalk rock, with the granulometric composition of medium silty loam (the textural class according to the standard BN-78/9180-11). According to a new classification of the Polish Society of Soil Science, it was loam. This soil was classified as soil class IIIb and defective wheat soil complex.

A three-factor field experiment evaluated the species composition, number and above-ground weight of weeds infesting a spelt wheat crop grown under different agronomic conditions grown in the same plots year after year. Two tillage systems, i.e. ploughing and ploughless tillage, were the first-order factor. Winter spelt wheat cultivars ('Frankenkorn', 'Badengold', 'Schwabenspeltz', 'Oberkulmer Rotkorn') were the second experimental factor. Moreover, the experimental design included the application of the herbicides Mustang 306 SE and Attribut 70 WG. Plots without chemical weed management were the control treatment. The experiment was set up as a split-plot design in three replicates and the harvested plot area was $8 \mathrm{~m}^{2}$. Common wheat was the previous crop for spelt wheat. Conventional tillage was performed in accordance with good agricultural practices. After the harvest of the previous crop, skimming and harrowing were done. Pre-sowing ploughing with harrowing was carried out 3 weeks before sowing spelt wheat. The field was also harrowed immediately before sowing spelt wheat. In the no-ploughing treatment, cultivating and harrowing were done after the harvest of the previous crop and subsequently cultivating and harrowing were repeated before sowing. Spelt spikelets were sown in mid-October at a rate of $350 \mathrm{~kg}$ per hectare. The herbicides Mustang $306 \mathrm{SE}\left(6.25 \mathrm{~g} \times \mathrm{l}^{-1}\right.$ florasulam - a compound from the group of triazo- lopyrimidines, $300 \mathrm{~g} \times \mathrm{l}^{-1}$ 2,4-D EHE - a compound from the group of phenoxy acids) and Attribut $70 \mathrm{WG}$ (70\% propoxycarbazone - a compound from the group of sulfonylaminocarbonyltriazolinones, methyl ester of 2-benzoic acid sodium salt) were applied in spring at the tillering stage (BBCH 24-29) at the rates of $0.41 \times \mathrm{ha}^{-1}$ and $60 \mathrm{~g} \times \mathrm{ha}^{-1}$, respectively. Moreover, the fungicide Alert $375 \mathrm{SC}\left(125 \mathrm{~g} \times \mathrm{l}^{-1}\right.$ flusilazole a compound from the group of triazoles, $250 \mathrm{~g} \times \mathrm{l}^{-1}$ carbendazim - a compound from the group of benzimidazoles) at a rate of $11 \times$ ha $^{-1}$ and the growth regulator Stabilan $750 \mathrm{SL}\left(750 \mathrm{~g} \times 1^{-1}\right.$ chlormequat chloride) at a rate of $21 \times$ ha $^{-1}$ were applied in the herbicide-treated plots at the stem elongation stage (BBCH 3234). Mineral fertilization of spelt wheat was as follows (in $\mathrm{kg}$ of nutrient per hectare): N 60 (20+40); P 26.2; K 83.

Weed infestation was evaluated by the dry-weight-rank method at the dough stage $(85-87 \mathrm{BBCH})$ of spelt wheat. The number, species composition and above-ground dry weight of weeds were determined based on sampling areas delineated by a $1 \mathrm{~m}$ x $0.25 \mathrm{~m}$ quadrat frame in four randomly selected places in each plot. The obtained results were statistically analysed by four-way analysis of variance and least significant differences were calculated using Tukey's confidence half-intervals with an error rate of 5\%. ARStat software developed by the Computing Centre of the University of Life Sciences in Lublin was used for the calculations.

\section{RESULTS}

In the spelt wheat crop, a total of 36 weed species were identified and a major part of them (31 species) were dicotyledonous weeds. The number of taxa and the abundance of individuals of a given species per unit area were dependent on spelt cultivar (Table 1). On average over the 3-year study period, 11 dicotyledonous weed species and 4 monocotyledonous species were common for all the cultivars compared. The greatest species diversity of the segetal flora was found in the crop of cv. 'Oberkulmer Rotkorn'. Regardless of tillage system and chemical plant protection, in this plot the weed community comprised 30 species, among which only 4 were included in the group of monocotyledonous weeds. On average 7 species fewer were identified in the crops of 'Frankenkorn' and 'Schwabenspeltz', whereas the crop community of the spelt cultivar 'Badengold' was characterized by the lowest biodiversity (21 species). As far as the quantitative structure of weed communities is concerned, Galium aparine and Apera spica-venti were clear dominants in the crops of all spelt cultivars. In the total number of weeds, the above-mentioned species accounted together for $45.8 \%$ (the 
crop of cv. 'Oberkulmer Rotkorn') up to $57.1 \%$ (the crop of cv. 'Schwabenspeltz') (Fig. 1). Moreover, the following species showed quite high density: Stellaria media $(6.9 \%-12.5 \%)$, Papaver rhoeas $(6.2 \%-10.8 \%)$, and Fallopia convolvulus (5.1\%-8.0\%). The numerous populations of Setaria pumila (9.3\%) and Matricaria maritima ssp. inodora (6.4\%) additionally contributed to the weed community in the 'Oberkulmer Rotkorn' crop, while Viola arvensis (6.8\%) and Convolvulus arvensis $(6.3 \%)$ occurred in quite high numbers in the 'Frankenkorn' crop. The other taxa were found sporadically and their impact on weed infestation was low.

Table 1

Species composition and number of weeds $\left(\right.$ plants $\times \mathrm{m}^{-2}$ ) in the crops of the spelt wheat cultivars compared (regardless of tillage system and chemical crop protection) - mean for 2009-2011

\begin{tabular}{|c|c|c|c|c|}
\hline \multirow{2}{*}{ Weeds } & \multicolumn{4}{|c|}{ Cultivar } \\
\hline & 'Badengold' & 'Frankenkorn' & 'Oberkulmer Rotkorn' & 'Schwabenspeltz' \\
\hline \multicolumn{5}{|l|}{ Dicotyledonous } \\
\hline Galium aparine $\mathrm{L}$. & 19.3 & 10.4 & 14.0 & 21.7 \\
\hline Stellaria media (L.) Vill. & 8.0 & 1.7 & 3.8 & 5.0 \\
\hline Papaver rhoeas L. & 4.0 & 3.8 & 1.8 & 3.9 \\
\hline Fallopia convolvulus L. & 3.3 & 2.8 & 1.2 & 3.6 \\
\hline Convolvulus arvensis $\mathrm{L}$. & 2.1 & 2.2 & 1.5 & 0.6 \\
\hline Matricaria maritima ssp. inodora (L.) & 2.0 & 0.5 & 3.5 & 2.0 \\
\hline Viola arvensis Murray & 2.0 & 2.4 & 0.7 & 1.0 \\
\hline Consolida regalis Gray & 1.0 & 0.8 & 0.3 & 0.4 \\
\hline Veronica arvensis L. & 0.8 & 0.1 & 0.6 & 0.6 \\
\hline Sonchus arvensis L. & 0.3 & - & 0.3 & 0.3 \\
\hline Myosotis arvensis (L.) Hill & 0.2 & 0.4 & 2.1 & 2.5 \\
\hline Cirsium arvense $\mathrm{L}$. & 0.2 & 0.3 & 1.2 & 1.0 \\
\hline Galinsoga parviflora Cav. & 0.1 & - & 0.1 & 0.1 \\
\hline Anagallis arvensis L. & 0.1 & - & - & - \\
\hline Veronica persica Poir. & 0.1 & - & 0.1 & 0.2 \\
\hline Cerastium arvense $\mathrm{L}$. & 0.1 & 0.1 & 0.2 & - \\
\hline Vicia hirsuta (L.) Gray & - & 0.6 & - & 0.1 \\
\hline Portulaca oleracea L. & - & 0.2 & - & - \\
\hline Conyza canadensis $\mathrm{L}$. & - & 0.1 & 0.1 & - \\
\hline Polygonum aviculare $\mathrm{L}$. & - & 0.1 & 0.2 & - \\
\hline Chenopodium album $\mathrm{L}$. & - & 0.1 & - & - \\
\hline Melandrium album (Mill.) Garcke & - & $0.0^{*}$ & 0.4 & 0.1 \\
\hline Geranium pusillum L. & - & 0.0 & 0.2 & - \\
\hline Artemisia vulgaris L. & - & - & 1.6 & 0.2 \\
\hline Eupatorium cannabinum L. & - & - & 0.8 & 0.2 \\
\hline Sonchus oleraceus L. & - & - & 0.1 & - \\
\hline Daucus carota $\mathrm{L}$. & - & - & 0.1 & - \\
\hline Arnoseris minima (L.) Schweigg. \& Körte & - & - & 0.1 & - \\
\hline Pastinaca sativa $\mathrm{L}$ & - & - & 0.1 & - \\
\hline Taraxacum officinale F. H. Wigg. & - & - & 0.1 & - \\
\hline Plantago major L. & - & - & - & 0.1 \\
\hline Number of species & 16 & 19 & 26 & 19 \\
\hline \multicolumn{5}{|l|}{ Monocotyledonous } \\
\hline Apera spica-venti $\mathrm{L}$. & 16.2 & 6.0 & 11.1 & 14.2 \\
\hline Setaria pumila (Poir.) Roem. \& Schult & 2.2 & 1.8 & 5.1 & 3.0 \\
\hline Echinochloa crus-galli L. & 1.2 & 0.6 & 2.0 & 1.0 \\
\hline Poa aпnиa $\mathrm{L}$. & 0.8 & - & - & - \\
\hline Elymus repens L. & 0.1 & 0.1 & 1.4 & 1.1 \\
\hline Number of species & 5 & 4 & 4 & 4 \\
\hline
\end{tabular}

$0.0^{*}$ species occurring at less than 0.1 plants $\times \mathrm{m}^{-2}$ 


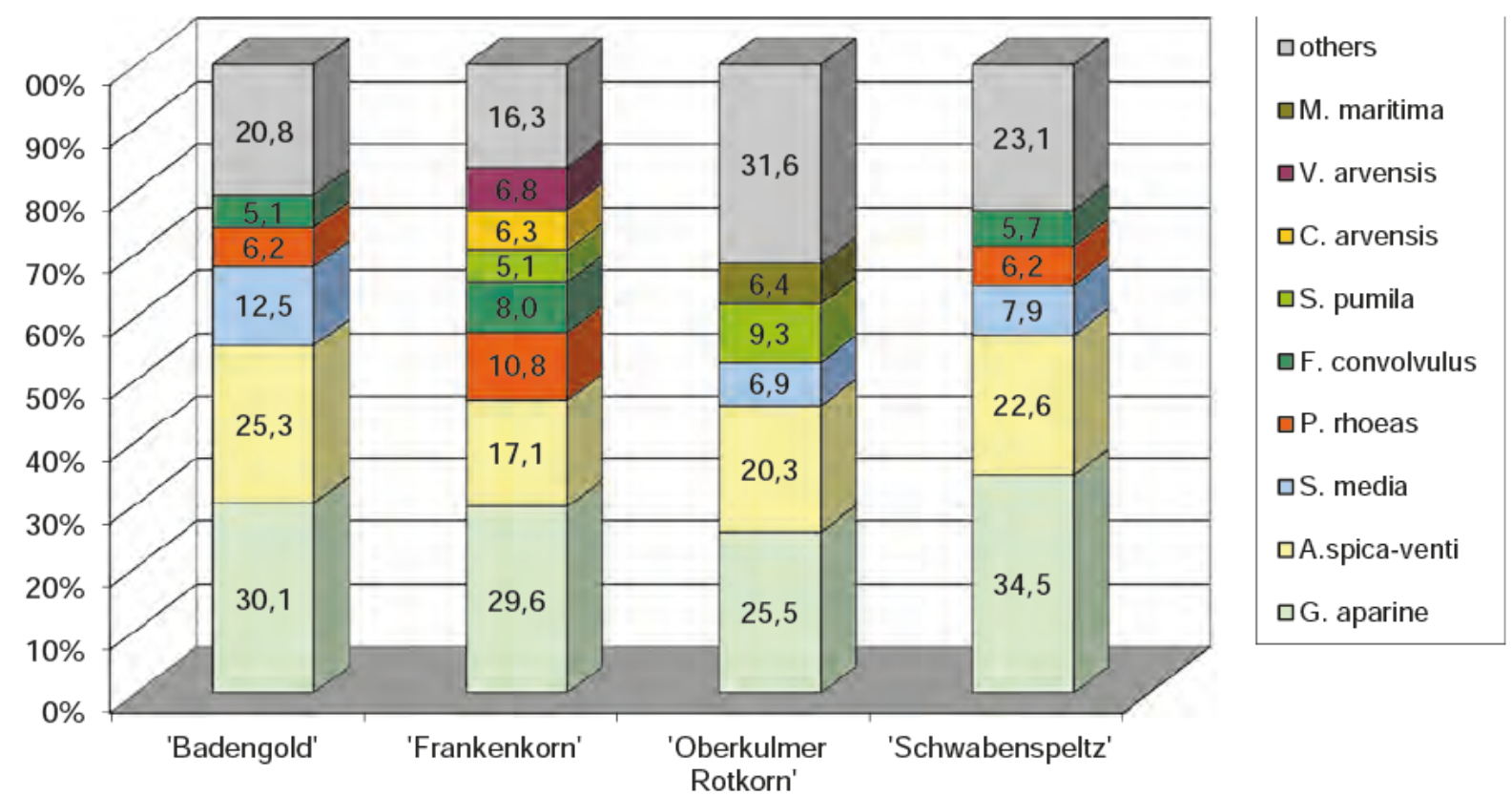

Fig. 1. Percentage of dominant weed species in the total number of weeds in the crops of the spelt wheat cultivars compared (mean for 2009-2011).

Table 2

Effect of experimental factors on the species composition and number of weeds (plants $\times \mathrm{m}^{-2}$ ) in the crop of cv. 'Badengold' (mean for 2009-2011)

\begin{tabular}{|c|c|c|c|c|}
\hline \multirow[b]{2}{*}{ Weeds } & \multicolumn{2}{|c|}{ Tillage system } & \multicolumn{2}{|c|}{ Chemical weed control } \\
\hline & Ploughing & Ploughless & $\begin{array}{l}\text { Control treatment } \\
\text { without herbicides }\end{array}$ & $\begin{array}{c}\text { Treatment } \\
\text { with herbicides }\end{array}$ \\
\hline \multicolumn{5}{|l|}{ Dicotyledonous } \\
\hline Galium aparine $\mathrm{L}$. & 21.5 & 17.3 & 20.6 & 18.2 \\
\hline Stellaria media (L.) Vill. & 7.3 & 8.7 & 8.4 & 7.6 \\
\hline Fallopia convolvulus L. & 4.0 & 2.7 & 2.4 & 4.3 \\
\hline Viola arvensis Murray & 3.8 & 0.2 & 2.0 & 2.0 \\
\hline Matricaria maritima ssp. inodora (L.) & 2.3 & 1.7 & 3.6 & 0.4 \\
\hline Papaver rhocas L. & 1.8 & 6.1 & 4.2 & 3.7 \\
\hline Convolvulus arvensis $\mathrm{L}$. & 1.6 & 2.6 & 1.3 & 2.9 \\
\hline Veronica arvensis $\mathrm{L}$. & 1.6 & 0.1 & 0.7 & 1.0 \\
\hline Consolida regalis Gray & 1.3 & 0.6 & 1.4 & 0.5 \\
\hline Sonchus arvensis L. & 0.6 & - & 0.2 & 0.4 \\
\hline Myosotis arvensis (L.) Hill & 0.2 & 0.2 & 0.2 & 0.2 \\
\hline Cirsium arvense $\mathrm{L}$. & 0.3 & 0.1 & 0.1 & 0.3 \\
\hline Anagallis arvensis $\mathrm{L}$. & 0.2 & - & 0.2 & - \\
\hline Galinsoga parviflora Cav. & 0.1 & 0.1 & 0.2 & - \\
\hline Cerastium arvense $\mathrm{L}$. & 0.1 & - & - & 0.1 \\
\hline Veronica persica Poir. & - & 0.2 & - & 0.2 \\
\hline Number of species & 15 & 13 & 14 & 14 \\
\hline \multicolumn{5}{|l|}{ Monocotyledonous } \\
\hline Apera spica-venti $\mathrm{L}$. & 15.9 & 16.6 & 20.5 & 11.9 \\
\hline Echinochloa crus-galli L. & 2.2 & 0.2 & 1.2 & 1.2 \\
\hline Setaria pumila (Poir.) Roem. \& Schult & 1.2 & 3.1 & 3.2 & 1.1 \\
\hline Poa аппиа L. & 0.2 & 1.3 & 0.9 & 0.7 \\
\hline Elymus repens L. & 0.2 & - & - & 0.2 \\
\hline Number of species & 5 & 4 & 4 & 5 \\
\hline
\end{tabular}


The weed species composition changed under the influence of reduced tillage used. Irrespective of chemical weed control, in the conventionally tilled plots the weed communities infesting the spelt crops numbered from 17 (cv. 'Schwabenspeltz') to 22 weed species (cv. 'Oberkulmer Rotkorn'), while under the ploughless tillage system from 17 (cv. 'Badengold') to 26 taxa (cv. 'Oberkulmer Rotkorn') (Tables 2-5). The greatest variation in the species composition as influenced by tillage system was found in the plots with cv. 'Oberkulmer Rotkorn' (Table 4). Over the 3-year study period, 4 species disappeared from the crop of this cultivar, whereas 8 new ones appeared which were not found under conventional tillage conditions. The numbers of particular species also changed, in particular in the group of dominant weeds. As a result of the use of reduced tillage, the numbers of A. spica- -venti increased and at the same time the occurrence of G. aparine decreased.

Regardless of tillage system, the herbicides used differentiated the weed species composition in the spelt crops. The number of taxa in the herbicide-treated plots was generally higher than in the treatment without chemical weed management. In this respect, the largest differences related to the cultivars 'Frankenkorn' and 'Oberkulmer Rotkorn' (Tables 3 and 4). Under the influence of herbicides, the number of taxa in the crops of the above-mentioned cultivars increased by 6 and 4 species, respectively. It should however be stressed that the herbicides evaluated reduced the occurrence of most weeds, including the most numerous species, i.e. G. aparine and A. spica-venti. High weed control efficacy of the agents used was also found in relation to $M$. maritima.

Table 3

Effect of experimental factors on the species composition and number of weeds (plants $\times \mathrm{m}^{-2}$ ) in the crop of cv. 'Frankenkorn' (mean for 2009-2011)

\begin{tabular}{|c|c|c|c|c|}
\hline \multirow{2}{*}{ Weeds } & \multicolumn{2}{|c|}{ Tillage system } & \multicolumn{2}{|c|}{ Chemical weed control } \\
\hline & Ploughing & Ploughless & $\begin{array}{l}\text { Control treatment } \\
\text { without herbicides }\end{array}$ & $\begin{array}{c}\text { Treatment } \\
\text { with herbicides }\end{array}$ \\
\hline \multicolumn{5}{|l|}{ Dicotyledonous } \\
\hline Galium aparine $\mathrm{L}$. & 13.4 & 7.4 & 13.1 & 7.8 \\
\hline Convolvulus arvensis L. & 3.6 & 0.9 & 2.7 & 1.8 \\
\hline Fallopia convolvulus L. & 2.8 & 2.9 & 2.8 & 2.9 \\
\hline Papaver rhoeas L. & 2.4 & 5.2 & 6.5 & 1.1 \\
\hline Viola arvensis Murray & 2.3 & 2.4 & 2.4 & 2.3 \\
\hline Stellaria media (L.) Vill. & 1.7 & 1.7 & 1.3 & 2.1 \\
\hline Matricaria maritima ssp. inodora (L.) & 0.8 & 0.2 & 0.6 & 0.4 \\
\hline Consolida regalis Gray & 0.8 & 0.7 & 0.8 & 0.7 \\
\hline Myosotis arvensis (L.) Hill & 0.7 & 0.1 & 0.3 & 0.5 \\
\hline Cirsium arvense $\mathrm{L}$. & 0.6 & - & - & 0.6 \\
\hline Vicia hirsuta (L.) Gray & 0.5 & 0.6 & 1.0 & 0.1 \\
\hline Portulaca oleracea L. & 0.2 & 0.2 & - & 0.4 \\
\hline Cerastium arvense $\mathrm{L}$. & 0.2 & - & - & 0.2 \\
\hline Veronica arvensis $\mathrm{L}$. & 0.1 & 0.1 & - & 0.2 \\
\hline Chenopodium album $\mathrm{L}$. & 0.1 & - & - & 0.1 \\
\hline Conyza canadensis $\mathrm{L}$. & - & 0.2 & - & 0.2 \\
\hline Polygonum aviculare $\mathrm{L}$. & - & 0.2 & - & 0.2 \\
\hline Melandrium album (Mill.) Garcke & - & 0.1 & 0.1 & - \\
\hline Geranium pusillum L. & - & 0.1 & 0.1 & - \\
\hline Number of species & 15 & 16 & 12 & 17 \\
\hline \multicolumn{5}{|l|}{ Monocotyledonous } \\
\hline Apera spica-venti $\mathrm{L}$. & 6.5 & 5.5 & 6.9 & 5.1 \\
\hline Echinochloa crus-galli L. & 1.2 & $0.0^{*}$ & 0.2 & 1.0 \\
\hline Setaria pumila (Poir.) Roem. \& Schult & 1.0 & 2.7 & 2.0 & 1.7 \\
\hline Elymus repens $\mathrm{L}$. & - & 0.1 & - & 0.1 \\
\hline Number of species & 3 & 4 & 3 & 4 \\
\hline
\end{tabular}

$0.0^{*}$ explanations as in Table 1 
Table 4

Effect of experimental factors on the species composition and number of weeds (plants $\times \mathrm{m}^{-2}$ ) in the crop of cv. 'Oberkulmer Rotkorn' (mean for 2009-2011)

\begin{tabular}{|c|c|c|c|c|}
\hline \multirow[b]{2}{*}{ Weeds } & \multicolumn{2}{|c|}{ Tillage system } & \multicolumn{2}{|c|}{ Chemical weed control } \\
\hline & Ploughing & Ploughless & $\begin{array}{l}\text { Control treatment } \\
\text { without herbicides }\end{array}$ & $\begin{array}{c}\text { Treatment } \\
\text { with herbicides }\end{array}$ \\
\hline \multicolumn{5}{|l|}{ Dicotyledonous } \\
\hline Galium aparine $\mathrm{L}$. & 19.1 & 9.0 & 15.1 & 13.0 \\
\hline Stellaria media (L.) Vill. & 5.6 & 2.0 & 4.2 & 3.4 \\
\hline Matricaria maritima ssp. inodora (L.) & 3.4 & 3.6 & 5.4 & 1.6 \\
\hline Artemisia vulgaris $\mathrm{L}$. & 2.9 & 0.4 & 1.3 & 2.0 \\
\hline Myosotis arvensis (L.) Hill & 1.6 & 2.6 & 1.4 & 2.7 \\
\hline Papaver rhoeas L. & 1.5 & 2.1 & 1.4 & 2.2 \\
\hline Fallopia convolvulus L. & 1.4 & 0.9 & 1.7 & 0.6 \\
\hline Veronica arvensis L. & 1.2 & 0.1 & 0.8 & 0.5 \\
\hline Convolvulus arvensis $\mathrm{L}$. & 1.0 & 2.0 & 2.3 & 0.7 \\
\hline Viola arvensis Murray & 1.0 & 0.4 & 1.4 & 0.1 \\
\hline Consolida regalis Gray & 0.6 & - & 0.4 & 0.2 \\
\hline Cirsium arvense $\mathrm{L}$. & 0.4 & 1.9 & 0.8 & 1.5 \\
\hline Galinsoga parviflora Cav. & 0.3 & - & 0.2 & 0.1 \\
\hline Melandrium album (Mill.) Garcke & 0.2 & 0.7 & 0.2 & 0.7 \\
\hline Cerastium arvense $\mathrm{L}$. & 0.2 & 0.2 & 0.4 & - \\
\hline Eupatorium cannabinum $\mathrm{L}$. & 0.1 & 1.6 & 1.4 & 0.3 \\
\hline Sonchus arvensis $\mathrm{L}$. & 0.1 & 0.4 & 0.4 & 0.1 \\
\hline Arnoseris minima (L.) Schweigg. \& Körte & 0.1 & - & 0.1 & - \\
\hline Taraxacum officinale F. H. Wigg. & 0.1 & - & 0.1 & - \\
\hline Polygonum aviculare $\mathrm{L}$. & - & 0.4 & 0.2 & 0.2 \\
\hline Geranium pusillum L. & - & 0.4 & - & 0.4 \\
\hline Conyza canadensis $\mathrm{L}$. & - & 0.2 & - & 0.2 \\
\hline Sonchus oleraceus L. & - & 0.2 & - & 0.2 \\
\hline Veronica persica Poir. & - & 0.2 & - & 0.2 \\
\hline Daucus carota $\mathrm{L}$. & - & 0.1 & - & 0.1 \\
\hline Pastinaca sativa $\mathrm{L}$. & - & 0.1 & - & 0.1 \\
\hline Number of species & 19 & 22 & 20 & 23 \\
\hline \multicolumn{5}{|l|}{ Monocotyledonous } \\
\hline Apera spica-venti $\mathrm{L}$. & 8.5 & 13.6 & 13.6 & 8.5 \\
\hline Setaria pumila (Poir.) Roem. \& Schult & 8.2 & 2.0 & 3.1 & 7.1 \\
\hline Echinochloa crus-galli L. & 2.2 & 1.8 & 2.7 & 1.3 \\
\hline Elymus repens L. & - & 2.9 & - & 2.9 \\
\hline Number of species & 3 & 4 & 3 & 4 \\
\hline
\end{tabular}

Cv. 'Frankenkorn' was the least weed-infested among the cultivars in question. The number of weeds accompanying this cultivar was significantly lower compared to the other cultivars, on average from $34.9 \%$ to $45.2 \%$ (Table 6). At the same time, the above-ground dry weight of weeds in the crop of 'Frankenkorn' significantly differed compared to cvs. 'Badengold' and 'Schwabenspeltz', respectively by $29.9 \%$ and $43.8 \%$ (Table 7). The use of reduced tillage, regardless of the other experimental factors, did not have a significant im- pact on the numbers of weeds colonising the spelt wheat crop, but the study showed a significant interaction between tillage systems and the cultivars in question (Table 6). A significant increase in the number of weeds in the reduced tillage treatment was only found in the plots sown with cv. 'Schwabenspeltz', whereas a slight decrease in weed density was observed in the crops of the other cultivars compared to ploughing tillage. At the same time, the dry weight of weeds in the unploughed plots was significantly higher on average by $30.6 \%$ than 
in the conventional tillage treatment (Table 7). The interaction found between tillage systems and years showed significant differences in the value of this weed infestation parameter only in 2010. In the other years, an increase in weed dry weight as influenced by ploughless tillage was small and statistically insignificant.

Regardless of the other experimental factors, herbicide application significantly decreased the number of weeds per unit area, on average by $17.2 \%$ compared to the control treatment without chemical protection (Table 6). The air-dry weight of weeds was clearly reduced more effectively (on average by $57.6 \%$ ), but the greatest weed-killing effect was found in the 'Frankenkorn' crop (on average by 67.9\%) (Table 7). Throughout the study period, the herbicides evaluated decreased weed dry weight on average by $50.2 \%$ to $70.5 \%$, but significant differences in the value of this trait, relative to the no-herbicide treatment, were found only in 2009 and 2010. The experiment showed a significant interaction of tillage system and chemical crop protection. A reduction in the number of weeds as influenced by herbicides was found under both conventional and reduced tillage (respectively by $18.7 \%$ and $15.6 \%$ ), but statistically confirmed significant differences related only to the conventionally tilled plots. Moreover, the herbicides used significantly differentiated the air-dry weight of weeds in the tillage systems compared. In the plots without chemical protection, the value of this trait was significantly higher by $34.3 \%$ than in the ploughed treatments, but in the herbicide-treated plots the increase in weed weight as a result of reduced tillage was statistically insignificant and it was $22.1 \%$.

Table 5

Effect of experimental factors on the species composition and number of weeds (plants $\times \mathrm{m}^{-2}$ ) in the crop of cv. 'Schwabenspeltz' (mean for 2009-2011)

\begin{tabular}{|c|c|c|c|c|}
\hline \multirow{2}{*}{ Weeds } & \multicolumn{2}{|c|}{ Tillage system } & \multicolumn{2}{|c|}{ Chemical weed control } \\
\hline & Ploughing & Ploughless & $\begin{array}{l}\text { Control treatment } \\
\text { without herbicides }\end{array}$ & $\begin{array}{c}\text { Treatment } \\
\text { with herbicides }\end{array}$ \\
\hline \multicolumn{5}{|l|}{ Dicotyledonous } \\
\hline Galium aparine $\mathrm{L}$. & 22.2 & 21.2 & 26.8 & 16.6 \\
\hline Fallopia convolvulus L. & 5.2 & 2.0 & 4.1 & 3.1 \\
\hline Stellaria media (L.) Vill. & 4.1 & 6.0 & 4.2 & 5.9 \\
\hline Myosotis arvensis (L.) Hill & 2.5 & 2.5 & 2.4 & 2.6 \\
\hline Papaver rhoeas $\mathrm{L}$. & 2.3 & 5.5 & 4.1 & 3.7 \\
\hline Viola arvensis Murray & 1.8 & 0.2 & 1.1 & 0.9 \\
\hline Convolvulus arvensis $\mathrm{L}$. & 1.3 & - & 1.1 & 0.2 \\
\hline Veronica arvensis L. & 1.1 & 0.1 & - & 1.2 \\
\hline Matricaria maritima ssp. inodora (L.) & 0.9 & 3.0 & 2.5 & 1.4 \\
\hline Consolida regalis Gray & 0.2 & 0.5 & 0.1 & 0.6 \\
\hline Artemisia vulgaris L. & 0.2 & 0.2 & 0.2 & 0.2 \\
\hline Veronica persica Poir. & 0.2 & 0.2 & 0.2 & 0.2 \\
\hline Plantago major L. & 0.2 & - & 0.2 & - \\
\hline Cirsium arvense $\mathrm{L}$. & - & 2.1 & 1.0 & 1.1 \\
\hline Sonchus arvensis L. & - & 0.7 & 0.4 & 0.2 \\
\hline Eupatorium cannabinum $\mathrm{L}$. & - & 0.3 & 0.3 & - \\
\hline Vicia hirsuta (L.) Gray & - & 0.2 & 0.2 & - \\
\hline Galinsoga parviflora Cav. & - & 0.2 & - & 0.2 \\
\hline Melandrium album (Mill.) Garcke & - & 0.1 & - & 0.1 \\
\hline Number of species & 13 & 17 & 16 & 16 \\
\hline \multicolumn{5}{|l|}{ Monocotyledonous } \\
\hline Apera spica-venti $\mathrm{L}$ & 8.1 & 20.2 & 13.3 & 15.0 \\
\hline Setaria pumila (Poir.) Roem. \& Schult & 3.2 & 2.9 & 1.8 & 4.3 \\
\hline Elymus repens $\mathrm{L}$. & 0.4 & 1.9 & 2.0 & 0.3 \\
\hline Echinochloa crus-galli L. & 0.2 & 1.8 & 0.6 & 1.3 \\
\hline Number of species & 4 & 4 & 4 & 4 \\
\hline
\end{tabular}


Table 6

Number of weeds in the spelt wheat crop depending on experimental factors (plants $\times \mathrm{m}^{-2}$ ), mean for 2009-2011

\begin{tabular}{|c|c|c|c|c|c|c|c|c|c|}
\hline \multirow{3}{*}{ Cultivar } & \multicolumn{9}{|c|}{ Tillage system } \\
\hline & \multicolumn{3}{|c|}{ Ploughing } & \multicolumn{3}{|c|}{ Ploughless } & \multicolumn{3}{|c|}{ Mean } \\
\hline & $\mathrm{C}^{* *}$ & $\mathrm{H}^{* * *}$ & Mean & $\mathrm{C}$ & $\mathrm{H}$ & Mean & $\mathrm{C}$ & $\mathrm{H}$ & Mean \\
\hline 'Frankenkorn' & 46.4 & 31.4 & 38.9 & 35.1 & 27.6 & 31.3 & 40.8 & 29.5 & 35.1 \\
\hline 'Badengold' & 72.9 & 59.9 & 66.4 & 69.7 & 54.0 & 61.8 & 71.3 & 56.9 & 64.1 \\
\hline 'Schwabenspeltz' & 59.3 & 48.7 & 54.1 & 74.0 & 69.5 & 71.8 & 66.6 & 59.1 & 62.9 \\
\hline 'Oberkulmer R.' & 62.8 & 56.6 & 59.7 & 54.4 & 45.3 & 49.8 & 58.6 & 50.9 & 54.8 \\
\hline Mean & 60.4 & 49.1 & 54.8 & 58.2 & 49.1 & 53.7 & 59.3 & 49.1 & - \\
\hline LSD 0.05 & \multicolumn{9}{|c|}{$\begin{array}{l}\text { cultivar } 10.0 \\
\text { chemical protection } 5.4 \\
\text { tillage system x chemical protection } 10.0 \\
\text { cultivar } x \text { tillage system } 16.7\end{array}$} \\
\hline
\end{tabular}

$\mathrm{C}^{* *}$ - control treatment without herbicides; $\mathrm{H}^{* * *}$ - treatment with herbicides

Table 7

Air-dry weight of weeds in the spelt wheat crop depending on experimental factors $\left({\left.\mathrm{g} \times \mathrm{m}^{-2}\right)}^{-2}\right.$

\begin{tabular}{|c|c|c|c|c|c|c|c|c|c|}
\hline \multirow{3}{*}{ Experimental factor } & \multicolumn{9}{|c|}{ Tillage system } \\
\hline & \multicolumn{3}{|c|}{ Ploughing } & \multicolumn{3}{|c|}{ Ploughless } & \multicolumn{3}{|c|}{ Mean } \\
\hline & $\mathrm{C}^{* *}$ & $\mathrm{H}^{* * *}$ & Mean & $\mathrm{C}$ & $\mathrm{H}$ & Mean & $\mathrm{C}$ & $\mathrm{H}$ & Mean \\
\hline \multicolumn{10}{|l|}{ Cultivar } \\
\hline 'Frankenkorn' & 86.1 & 27.2 & 56.6 & 112.6 & 36.7 & 74.6 & 99.3 & 31.9 & 65.6 \\
\hline 'Badengold' & 115.5 & 53.1 & 84.3 & 152.0 & 53.9 & 102.9 & 133.7 & 53.5 & 93.6 \\
\hline 'Schwabenspeltz' & 140.1 & 74.8 & 107.4 & 163.5 & 88.4 & 125.9 & 151.8 & 81.6 & 116.7 \\
\hline 'Oberkulmer R.' & 87.1 & 36.4 & 61.8 & 148.0 & 54.9 & 101.5 & 117.6 & 45.7 & 81.6 \\
\hline \multicolumn{10}{|l|}{ Year } \\
\hline 2009 & 113.4 & 48.0 & 80.7 & 156.5 & 31.7 & 94.1 & 134.9 & 39.8 & 87.4 \\
\hline 2010 & 174.9 & 82.6 & 128.8 & 238.2 & 122.8 & 180.5 & 206.5 & 102.8 & 154.6 \\
\hline 2011 & 33.2 & 12.9 & 23.1 & 37.4 & 20.9 & 29.2 & 35.3 & 16.9 & 26.1 \\
\hline Mean & 107.2 & 47.9 & 77.5 & 144.0 & 58.5 & 101.2 & 125.6 & 53.2 & - \\
\hline LSD 0.05 & \multicolumn{9}{|c|}{$\begin{array}{l}\text { cultivar } 23.8 \\
\text { tillage system } 12.8 \\
\text { chemical protection } 12.8 \\
\text { cultivar x chemical protection } 39.9 \\
\text { tillage system x chemical protection } 23.8 \\
\text { year } 18.8 \\
\text { year x tillage system } 32.5 \\
\text { year x chemical protection } 32.5\end{array}$} \\
\hline
\end{tabular}

\section{DISCUSSION}

Under the conditions of the present experiment, the spelt wheat crop was infested with species typical of winter cereals grown on rendzina soil $[17,18,19]$. Galium aparine and Apera spica-venti were found in greatest numbers in the crops of all spelt wheat cultivars compared. A similar tendency was observed in the spelt crops of cvs. 'Schwabenkorn' and 'Spelt I.N.Z.' [17]. In the study of Feledy n-S zewczyk [16], segetal communities in the spelt crop of cv. 'Schwabenkorn' were represented in greatest numbers by Apera spica-venti and Viola arvensis, whereas in the study of Pałys and Kuraszkiewicz [20] weed infestation of the crops of four spelt cultivars ('Bauländer Spelz', 'Schwabenkorn', 'Rouquin', and 'Loge') was determined by Veronica arvensis, Viola arvensis, Stellaria media, Convolvulus arvensis, and Matricaria maritima ssp. inodora. 
Many authors indicate that a properly selected cultivar, competitive against weeds, can be the least costly weed management method [14, 21, 22]. In the present experiment, cv. 'Frankenkorn' was the most competitive against weeds and it was characterized by the lowest number and weight of weeds in the crop compared to the other ones. In assessing weed infestation of the crops of winter spelt wheat cultivars ('Badengold', 'Schwabenspeltz' and 'Schwabenkorn'), K r a w c z y k and $\mathrm{S}$ u lew ska [23] did not show significant differences in the number and biomass of weeds between the cultivars tested. Korres and Froud-Willi a m s [24] as well as M a s o n and S pan e r [15] think that plant height, tillering ability, and increased crop density all play an important role in the competitive effect of winter wheat cultivars on weeds. Similarly, P a r y $1 \mathrm{ak}$ et al. [22] think that weed control that takes into account the weed-competitive ability of cultivars requires the knowledge and characteristics of traits that are responsible for this ability. In evaluating winter wheat cultivars, Fe ledy n-S z e w c z y k and Duer [25] found the spelt wheat cultivar 'Schwabenkorn' and the common wheat cultivar 'Mewa' to have the largest number of favourable traits that were conducive to competitiveness against weeds, which was primarily determined by traits such as leaf area, plant tillering, plant height, or biomass accumulation rate.

In the present study, tillage system did not affect the numbers of weeds in the spelt wheat crop, but the air-dry weight of weeds changed significantly. Thus, this study confirmed the reports both from foreign [26, 27] and national literature $[9,28,29]$ concerning increased weed infestation under reduced tillage conditions. J ę d ruszczak and Antos zek [7] observe that weed species associated only with the conditions that have been created as a result of reduced tillage are few and they appear in small numbers, whereas we can expect distinct changes in agrophytocenoses as influenced by tillage system after a period longer than three years of the effects of the tillage factor. In the present study, reduced tillage clearly caused an increased dominance of Apera spica-venti and at the same time a reduced occurrence of Galium aparine. An increase in the numbers of A. spica-venti under the influence of ploughless tillage is reported by $\mathrm{Kraska}$ and $\mathrm{P}$ ał y s [30]. In the study of Frant and $\mathrm{Bujak}$ [31], replacing autumn ploughing with cultivating or harrowing increased the numbers of Apera spica-venti, Galinsoga ciliata and Elymus repens, while Viola arvensis occurred in distinctly lower numbers. Likewise, W e b e $r$ and Hry ń z z k [9] observed higher weed infestation of winter wheat cultivars under no-ploughing conditions, but in some years certain weed species (Geranium dissectum, Stellaria media, Capsella bursa-pastoris) developed in greater numbers under the conventional tillage system. The above-mentioned authors explain this fact by the varying ability to adapt to extreme environmental conditions found in the plants studied.

In the present study, herbicides significantly reduced the number and above-ground weight of weeds, but they did not have a large effect on the number of species present in the communities. Stupnicka-Rodzynkiewicz et al. [12] presented a direction of changes in a weed community similar to the one presented in this study. In the opinion of these authors, herbicide application reduces the numbers of weeds but not their diversity. Therefore, we should not be afraid that chemical weed control will result in species impoverishment of an agrophytocenosis. Rola et al. [32] also think that rational herbicide application can pose a threat to species diversity of agrophytocenoses only to a limited extent. On the other hand, the long-term observations of $\mathrm{J}$ ę $\mathrm{drus} \mathrm{zczak}$ and $\mathrm{A} \mathrm{n}$ t o s ze k [7] show that with the passage of time herbicides distinctly reduced weed biodiversity in winter wheat crops, which resulted from the increasing dominance of Apera spica-venti.

\section{CONCLUSIONS}

1. Galium aparine and Apera spica-venti were the dominant weed species in the crops of the spelt wheat cultivars compared.

2. Both chemical weed management and tillage system only slightly changed the number of weed species in the spelt crop, but the cultivars evaluated had a clearly differentiating effect on the biodiversity of the agrophytocenoses. The largest number of weed species was found in the crop of cv. 'Oberkulmer Rotkorn'.

3. Cv. 'Frankenkorn' exhibited the highest weed-competitive ability. The number and above-ground dry weight of weeds in the crop of this cultivar were lower compared to the other cultivars.

4. The use of reduced tillage, regardless of the other experimental factors, significantly increased weed dry weight compared to ploughing tillage. However, it should be indicated that under ploughless tillage conditions the use of chemical crop protection significantly reduced weed biomass in relation to the control treatments without crop protection.

\section{Acknowledgements}

Research supported by the Ministry of Science and Higher Education of Poland as part of the statutory activities of the Department of Agricultural Ecology, University of Life Sciences in Lublin. 


\section{Authors' contributions}

The following declarations about authors' contributions to the research have been made: design of the experiments: EP; field research and data analysis: EKP, PK, SA; writing the manuscript: SA.

\section{REFERENCES}

1. Dzienia S, Zimny L, Weber R. Najnowsze kierunki w uprawie roli i technice siewu. / The newest trends in soil tillage and techniques of sowing. Fragm Agron. 2006; 23 (2): 227-241 (in Polish).

2. Holla nd J M. The environmental consequences of adopting conservation tillage in Europe: reviewing the evidence. Agric Ecosyst Environ. 2004; 103: 1-25. http://dx.doi.org/ 10.1016/j.agee.2003.12.018.

3. Blecharczyk A, Małecka I, Sierpowski J. Wpływ wieloletniego oddziaływania systemów uprawy roli na fizyko-chemiczne właściwości gleby. / Long-term effects of tillage systems on physico-chemical soil properties. Fragm Agron. 2007; 24 (1): 7-13 (in Polish).

4. Sekutowski T, Domaradzki K. Bioróżnorodność gatunkowa chwastów w monokulturze pszenicy ozimej w warunkach stosowania uproszczeń w uprawie roli. / Biodiversity of weed species in winter wheat monoculture caused by reduced of tillage. Fragm Agron. 2009; 26(4): 160-169 (in Polish).

5. Moyer JR, Roman ES, Lindwall CW, Black$\mathrm{sh}$ aw RE. Weed management in conservation tillage systems for wheat production in North and South America. Crop Prot. 1994; 13: 243-259. http://dx.doi.org/10.1016/ 0261-2194(94)90012-4.

6. Tuesca D, Puricelli E, Papa JC. A long-term study of weed flora shifts in different tillage systems. Weed Res. 2001; 41: 369-382. http://dx.doi.org/10.1046/j. 1365-3180.2001.00245.x.

7. Jędruszczak M, Antoszek R. Sposoby uprawy roli a bioróżnorodność zbiorowisk chwastów w monokulturze pszenicy ozimej. / Tillage system and biodiversity of weed communities in winter wheat monoculture. Acta Sci Pol Agricultura. 2004; 3(2): 47-59 (in Polish).

8. Małecka I, Blecharczyk A, Dobrzeniecki T. Zachwaszczenie zbóż ozimych w zależności od systemu uprawy roli. / Response of weed community in winter cereals to tillage system. Prog Plant Protection/Post Ochr Roślin 2006; 46(2): 253-255 (in Polish).

9. Weber R, Hryńczuk B. 2005. Wpływ sposobu uprawy roli i przedplonu na zachwaszczenie pszenicy ozimej. / Influence of forecrop and mode of tillage on weed infestation of winter wheat. Ann UMCS Sect. E. 2005; 60: 93-102 (in Polish).

10. Kraska P. Effect of tillage system and catch crop on weed infestation of spring wheat stands (Triticum aestivum L.). Acta Sci Pol Agricultura 2012; 11 (2): 27-43.

11. Tr z c ińs k a-Ta cik H. Znaczenie różnorodności gatunkowej chwastów segetalnych. / Importance of field weeds species diversity. Pam Pul. 2003; 134: 253-262. (in Polish)
12. Stupnicka-Rodzynkiewicz E, Stępnik K, Lepiarczyk A. Wpływ zmianowania, sposobu uprawy roli i herbicydów na bioróżnorodność zbiorowisk chwastów / Effect of the crop rotation, tillage method and herbicides on the biodiversity of of weed communities. Acta Sci Pol Agricultura 2004; 3(2): 235-245 (in Polish).

13. Lemerle D, Verbeek B, Cousens RD, Coombes NE. The potential for selecting wheat varieties strongly competitive against weeds. Weed Res. 1996; 36: 505-513. http://dx.doi.org/10.1111/j.1365-3180.1996. tb01679.x.

14. Feledyn-Szewczyk B, Duer I. 2005. Konkurencyjność kilku odmian pszenicy ozimej uprawianej w ekologicznym systemie produkcji w stosunku do chwastów. I Weed competitiveness of some winter wheat varieties cultivated in organic crop production system. Prog Plant Protection / Post Ochr Roślin. 2005; 45(1): 126-133 (in Polish).

15. Mas on HE, Spaner D. Competitive ability of wheat in conventional and organic management systems: a review of the literature. Can J Plant Sci. 2006; 86: 333-343. http://dx. doi.org/31.131.49.147on11/22/12.

16. Feledy n-S z ew c z y k B. Porównanie konkurencyjności współczesnych i dawnych odmian pszenicy ozimej w stosunku do chwastów. / Comparison of the competitiveness of modern and old winter wheat varieties in relation to weeds. J Res Appl Agric Eng. 2009; 54(3): 60-67 (in Polish).

17. Andruszczak S, Kraska P, KwiecińskaPoppe E, Pałys E. Weed infestation of crops of winter spelt wheat (Triticum aestivum ssp. spelta) cultivars grown under different conditions of mineral fertilization and chemical plant protection. Acta Agrobot. 2012; 65(3): 109-118.

18. Andruszczak S, Kraska P, KwiecińskaPoppe E, Pałys E. Biological diversity of weeds in a winter triticale (Triticum rimpaui Wittm.) crop depending on different doses of herbicides and foliar fertilization. Acta Agrobot. 2011; 64(2): 109-118.

19. Pałys E, Korzeniowski M, Andruszczak S, Kraska P, Krusińska B. Wpływ poziomu nawożenia mineralnego i ochrony chemicznej na zachwaszczenie łanu pszenicy ozimej wysiewanej po sobie na rędzinie. / The influence of mineral fertilization and chemical protection on weed infestation of winter wheat sown after winter wheat on rendzina soil. Zesz Probl Post Nauk Rol. 2011; 559: 141-151 (in Polish).

20. Pałys E, Kuraszkiewicz R. Wpływ terminów siewu odmian orkiszu (Triticum aestivum ssp. spelta) na zachwaszczenie. / The influence of sowing date on the weed infestation of spelt canopy. Zesz Probl Post Nauk Rol. 2003; 490: 179-186 (in Polish).

21. Christensen S. Weed suppression ability of spring barley varieties. Weed Res. 1995; 35: 241-247. http://dx. doi.org/10.1111/j.1365-3180.1995.tb01786.x.

22. Parylak D, Zawieja J, Jędruszczak M, Stupnicka-Rodzynkiewicz E, Dąbkowska T, Snarska K. Wykorzystanie zasiewów mieszanych, właściwości odmian lub zjawiska allelopatii w ograniczaniu zachwaszczenia. / Use of the mixed crops, cultivar properties 
or allelopathy in weed control. Prog Plant Protection / Post Ochr Roślin. 2006; 46(1): 33-44 (in Polish).

23. Krawczyk R, Sulewska H. Zachwaszczenie ozimych odmian orkiszu pszennego w zależności od nawożenia obornikiem. / Weed infestation of winter spelt varieties depending on manure fertilization. J Res Appl Agric Eng. 2012; 57(3): 216- 221 (in Polish).

24. Korres NE, Froud-Williams RJ. Effect of winter wheat cultivars and seed rate on the biological characteristics of naturally occurring weed flora. Weed Res. 2002; 42: 417428. http://dx.doi.org/10.1046/j.1365-3180.2002.00302.x.

25. Feledyn-Szewczyk B, Duer I. Ocena konkurencyjności odmian pszenicy ozimej uprawianej w ekologicznym systemie produkcji w stosunku do chwastów. / Assessment of weed competitiveness in relation to some winter wheat varieties cultivated in organic crop production system. J Res Appl Agric Eng. 2006; 51(2): 30-35 (in Polish).

26. Buhler D, Stoltenberg DE, Becker RL, Gunsolus J.L. Perennial weed populations after 14 years of variable tillage and cropping practices. Weed Sci. 1994; 42: 205-209.

27. Tørresen KS, Skuterud R. Plant protection in spring cereal production with reduced tillage. Changes in the weed flora and weed seedbank. Crop Prot. 2002; 21: 179193. http://dx.doi.org/10.1016/S0261-2194(01)00081-3.

28. Woźniak A. Zachwaszczenie pszenicy twardej w różnych systemach uprawy roli. / Weed infestation of durum wheat in different tillage systems. Ann UMCS Sect. E. 2010; 65: 56-63. http://dx.doi.org/10.2478/v10081-010-0007-z.

29. Orzech K, Rychcik B, Stępień A. Wpływ sposobów uprawy roli na zachwaszczenie i plonowanie jęczmienia jarego. / The influence of tillage systems on weed infestation and yield of spring barley. Fragm Agron. 2011; 28 (2): 63-70 (in Polish).

30. Kraska P, Pałys E. 2004. The influence of different cultivation technology on winter rye (Secale cereale $\mathrm{L}$.) weed infestation. XII International Conference on Weed Biology, Ann. AFPP, 31.08.-2.09.2007, Dijon France. 2004: 211-218.

31. Frant M, Bujak K. Wpływ uproszczeń w uprawie roli i poziomów nawożenia mineralnego na zachwaszczenie pszenicy jarej. / Influence of reduced tillage and level of fertilisation on spring wheat weed infestation. Acta Agrophys. 2006; 8 (2): 327-336 (in Polish).

32. Rola J, Rola H, Domaradzki K. Przyrodnicza optymalizacja zbiorowisk chwastów w agrocenozach /
Environmental optimalisation of weed communities in agro-ecosystems. Prog Plant Protection / Post Ochr Roślin. 2009; 49 (3): 1102-1111 (in Polish).

\section{Wpływ systemu uprawy roli i zastosowania herbicydów na zachwaszczenie łanu ozimych odmian pszenicy orkiszowej (Triticum aestivum ssp. spelta L.)}

\section{Streszczenie}

W 3-letnim doświadczeniu polowym przeprowadzonym na średnio ciężkiej rędzinie mieszanej oceniano wpływ chemicznej ochrony roślin na skład gatunkowy, liczbę i powietrznie suchą masę chwastów zasiedlających łany ozimych odmian pszenicy orkiszowej ('Frankenkorn', 'Badengold', 'Schwabenspeltz' i 'Oberkulmer Rotkorn') wysiewanych w warunkach płużnej i bezpłużnej uprawy roli. Uprawa płużna polegała na wykonaniu podorywki po zbiorze przedplonu oraz orki siewnej, zaś w uprawie bezpłużnej orkę zastąpiono kultywatorowaniem. Chemiczne zwalczanie chwastów uwzględniało zastosowanie środków Mustang 306 SE i Attribut 70 WG. Obiekt kontrolny stanowiły poletka, na których nie stosowano herbicydów.

Łany porównywanych odmian pszenicy orkisz zasiedlało średnio od 21 do 30 gatunków chwastów. Najliczniej występowały Galium aparine i Apera spica-venti, których udział w ogólnej liczbie chwastów oceniono odpowiednio na 26-35\% i 17-25\%. Najmniej zachwaszczona była odmiana 'Frankenkorn'. Zarówno liczba chwastów w łanie tej odmiany, jak i powietrznie sucha masa ich części nadziemnych były mniejsze $\mathrm{w}$ porównaniu $\mathrm{z}$ pozostałymi odmianami. Wprowadzenie uproszczeń w uprawie roli istotnie zwiększyło powietrznie suchą masę chwastów w porównaniu z płużnym systemem uprawy roli. Należy jednak zaznaczyć, iż w warunkach uprawy bezorkowej zastosowanie chemicznej ochrony zasiewów zmniejszyło masę chwastów o 59\% względem obiektów kontrolnych bez ochrony.

Handling Editor: Elżbieta Weryszko-Chmielewska

This is an Open Access digital version of the article distributed under the terms of the Creative Commons Attribution 3.0 License (creativecommons.org/licenses/by/3.0/), which permits redistribution, commercial and non-commercial, provided that the article is properly cited.

(CThe Author(s) 2013 Published by Polish Botanical Society 